\title{
Settlement and Land Tenure in the Peace Country: A Study of Township 83-25-W5
}

\author{
Robert Irwin
}

ABSTRACT: In recent years, historians such as Lyle Dick and Paul Voisey have begun to explore western Canadian settlement and land tenure patterns. Their studies demonstrate that an analysis of land ownership and utilisation is an important first step cowards a historical understanding of western Canadian agricultural society. This paper examines settlement and land tenure in one rownship in the Peace River country. Special problems of settlement in the Peace country, including the homestead system, timing, the Soldier Settlement Board, marginal lands, and distance from market, led to the early maruration of the community. Combined with the post First World War depression, these problems caused an early rationalisation of the population in the rownship leading to long term stability. This study provides another example of the varied agricultural experience in the west.

Historians have not made a substantial effort to scrutinise settlement patterns and land tenure in western Canada. Unlike the U.S. experience where the work of Paul Gates inspired numerous historians to look at land tenure, the early work by the Frontiers of Sectlement Series stood alone for a generation. ' Only in recent years have historians such as Lyle Dick and Paul Voisey begun to explore these issues. Their studies demonstrate that an analysis of land ownership and utilisation is an important first step towards a historical understanding of western Canadian agricultural society. This paper examines settlement and land tenure in a single township in the Peace River country of Northern Alberta. Using the homestead files, census statistics, and tax rolls of the Municipal district of Peace \#857, issues such as homestead cancellation rates, land sales, tenancy, and rates of persistence are examined. ${ }^{2}$ Although this paper suggests that certain characteristics identified with land utilisation are consistent with frontier socieries elsewhere, a monolithic frontier experience does not emerge. Instead, the settlement process and land tenure patterns highlight the importance of the timing of settlement in the Peace country and the distinctive local conditions encountered by the new agricultural community. 


\section{Settlement in Township 83-25-W5}

Between 1872 and 1903, the Peace River country was studied intermittently for its agricultural value. Many of the reports were quite favourable, but, in 1903, James Macoun, son of the famous botanist John Macoun, examined the region and offered a different opinion. Early frosts and a short growing season led him to conclude that the plateau was unsuitable for agriculture. ${ }^{3}$ The government, however, chose to ignore his recommendations; indeed they refuted his conclusions and began to survey the region for agriculture. Thus a region whose agricultural potential was questioned by scientists was opened to settlement.

Surveyed by J.H. Smith in 1911 and opened for settlement by the Department of the Interior in 1913, Township 83-25-W5 is located on the north side of the Peace River approximately forty miles from Peace River Crossing town site. The towns and villages in its proximity are Grimshaw, Berwyn, and Brownvale. It borders Lake Cardinal (called Bear Lake in 1911) on its northeastern corner and because of its proximity to the lake has easy access to well water. A small creek meanders through the northern sections, but, on the whole, the township is flat and arable. The township, one small part of the Fairview/Berwyn prairie, was described by J.H. Smith as $40 \%$ wooded with poplar and spruce up to 16 inches in diameter. The remainder was prairie and scrub with a black loam soil two to twelve inches thick over a clay loam sub-soil. The surveyor concluded the township was well suited to mixed farming and grazing. ${ }^{4}$

Township 83-25-W5 did not resemble the typical prairie township so often described in historical literature. ${ }^{5}$ In reality, few typical townships existed anywhere and the settlement opportunities varied from region to region. The townships in the Peace River district, however, were significantly different. The typical prairie township consisted of 36 sections divided into four quarter sections each. Sections 11 and 29 were designated school lands; section 8 and the south half and northwest quarter of section 26 were Hudson's Bay Company lands; all the remaining odd numbered sections were reserved for railway subsidies; and all the remaining even numbered sections were free homestead lands. The typical prairie township thus contained 65 quarters of homestead land, 64 quarters of railway land, 8 quarters of school land, and 7 quarters of $\mathrm{HBC}$ land. By the time the Dominion surveyed Township 83-25-W5, the railways had been forced to select and patent their reserved lands. ${ }^{6}$ Moreover, the $\mathrm{HBC}$ had no reserved lands in the Peace country. As a result, in township $83-25-$ W5, 8 quarters were designated school land, and section 36 and the northeast quarter of 


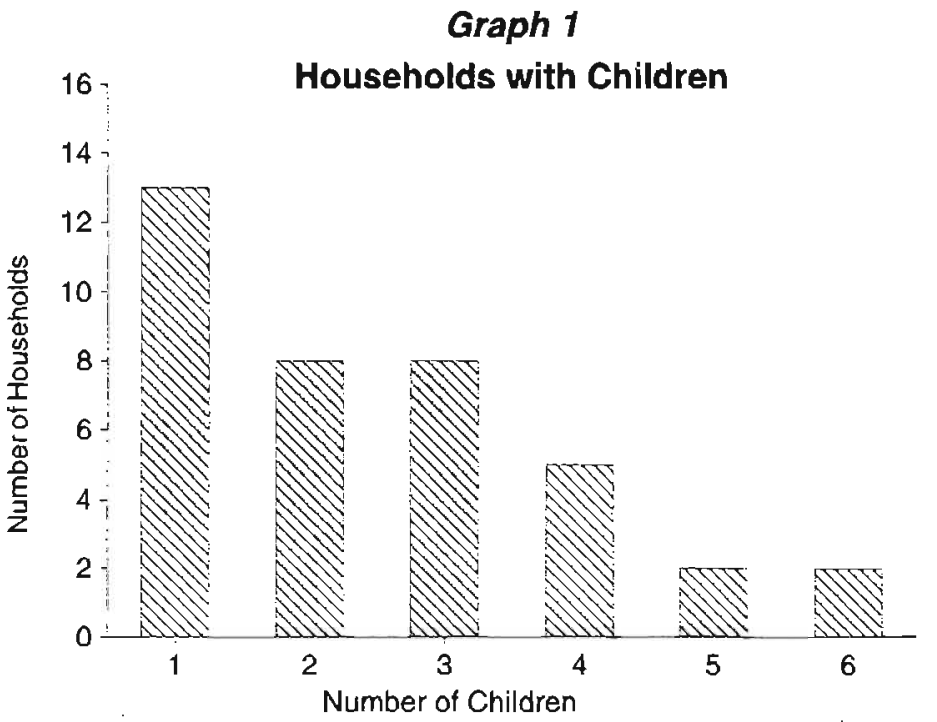

section 25 were unavailable because of the lake. All the remaining 131 quarters were free homestead land.

The commencement of homesteading in the district, therefore, resulted in a more compacted settlement pattern than was usual in the prairie west. Alex and Benjamin La Prette, a Metis family from Shaftesbury settlement in the Peace River valley, filed the first homesteads in the township on April 29, 1913 and June 14, 1913, respectively.? By the end of 1913, 31 claims for homesteads had been filed. The rapid pace of settlement continued in 1914 with 87 entries. The successful homesteaders were predominantly Canadians (36\%), Americans $(26.5 \%)$, British (16.5\%), and Scandinavians (8.5\%), with small numbers of Germans, Galicians, Russians, and French. In a pattern similar to that Voisey found in Vulcan, few settlers in township 83-25W5 came directly from their childhood homes. ${ }^{8}$ Over half had lived in Peace River, Edmonton, or elsewhere in Alberta before homesteading in the Berwyn district. Only 28 of the 126 homesteaders for which information is available came directly from the United States and only one from Europe. Two-thirds of them were single. Of the 38 married homesteaders, $86 \%$ had children. The average age at the time of homesteading was 32.5 years. The age distribution seems roughly to coincide with that found by Dick in the Abernethy district. ${ }^{9}$ (Graph 2)

One of the key tenets of the frontier thesis is the individualism of the frontier. Sectlers, alone on the frontier, were forced to co-operate with their neighbours and a degree of equality resulted. The settlement of 
Graph 2

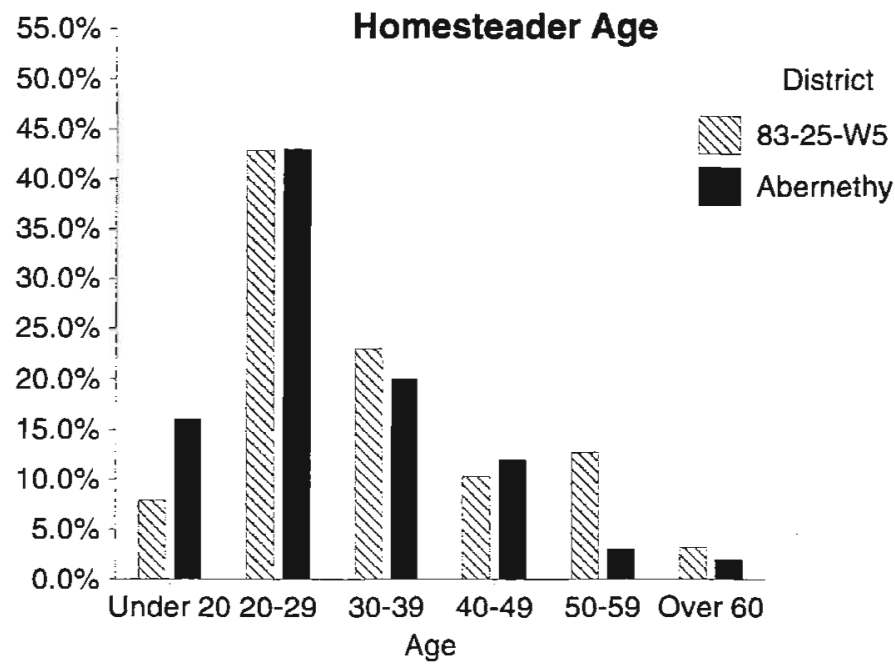

township 83-25-W5 suggests that the frontier may not have been such a lonely place. ${ }^{10}$ Many of the homesteaders arrived in the Peace country in family groups. Four members of the Cyra family, five Reyda's, three Fosberg's, and three Viala's, along with several brother-brother and father-son combinations, homesteaded in the township. In a few other cases, a non-familial relationship was discovered. Of the 115 homesteaders for which such information could be obtained, 42 arrived with family or friends.

A prospective settler, following the application for a homestead, had to "prove up" the land before a patent was issued. In the simplest sense, proving up required that the settler live on the homestead at least six months per year for three years and prepare thirty acres of his land for cropping. " Studies have shown that many homesteaders never succeeded in proving up their land, and, in Peace River, a similar trend was noticeable. As early as 1914 , entries were made on quarter sections where 1913 applications had been cancelled. Although 118 applications were made in the twenty months following Alex La Prette's initial homestead, only 99 of a possible 131 quarter sections had been claimed and only 68 of these would be proved up. Three or more applications for homestead were entered on 28 quarters. In all, $48 \%$ of the applications failed. Voisey found that $41 \%$ of applications in the Vulcan region failed and Dick found that around Neudorf only $28 \%$ cancelled. ${ }^{12}$ It would thus appear that a great deal of difficulty occurred in 


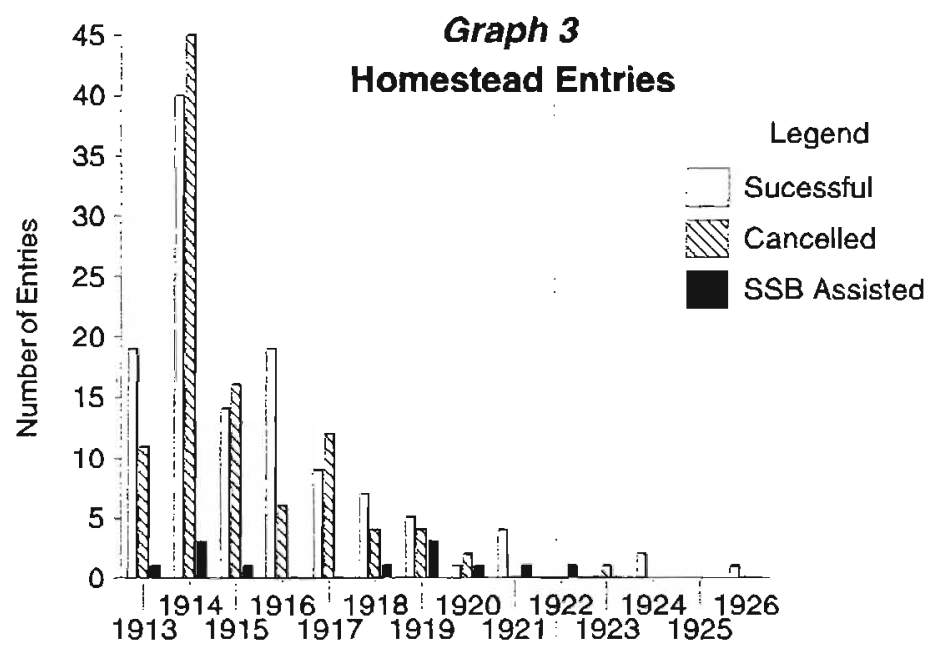

proving up in the Berwyn district. Care must be taken, however, when assessing the relevance of this information.

There were, undoubtedly, cases where homesteaders made an attempt at settlement and failed. It is apparent, nevertheless, that a number of cancellations occurred because the applicant for homestead never made an attempt to settle the land. The evidence for this hypothesis is limited, but suggestive. The Sobasky family, for example, filed for 4 quarters in 1913. ${ }^{13}$ John Sobasky filed all the applications on behalf of the family. The information in the files does not indicate why the family never took up residence, but it is obvious that they did not. When applying for patent on a homestead, the farmer had to provide information including the amount of land he had prepared for cropping. On the Sobasky homesteads and on several other cancelled homesteads, no evidence of any land prepared by the earlier homesteaders exists. Homesteads proved up by the original applicant showed that $8-10$ acres breaking in the first year was average. Homesteads proved up by the second or subsequent applicant showed no appreciable surplus breaking. In other cases, the appearance of two homestead applications on a quarter in rapid succession suggest that the first applicant made no attempt to take up residence. In 58 cases, the second application on a quarter was made within 18 months of the first.

One probable reason for this failure to make an attempt at farming was the misconception many settlers had about the land. Advertising for the Peace country made the region out to be a garden in the north 


\section{Past Imperfect}

and emphasised the open grass lands around Grande Prairie. It gave little indication of the significant differences the North Peace had from the southern prairie. Not only did raw prairie have to be broken, but, in most cases, trees had to be cleared. Homesteader John Bagan recalled that many of the farms were nothing more than small clearings in the bush with piles of cut trees occupying the centre of the field. ${ }^{14}$ The lack of railway facilities into the Peace country during the initial homestead period certainly had an impact on the high number of cancellations. The Edmonton, Dunvegan and British Columbia did not reach Peace River Crossing until 1916 and did not complete the bridge across the Peace until October 1918. The railhead remained 70 kilometres away from township 83-25-W5 until 1922 when it reached the new village of Berwyn. Until then, farmers wishing to market their grain had to make the long trip to the Crossing during the winter and descend treacherous Brick's Hill near the Shaftesbury settlement.

\section{The First to Leave}

"Speculation"

Land speculation is one issue of land tenure which has held the interest of historians. Early work emphasised the nefarious nature of the speculators and concluded that they had been harmful to the settlement process. Carl Dawson wrote in 1934:

The heterogenous elements included hundreds who never would become permanent settlers. For them the homesteads were to be sold, eventually, at a profit. They were there to make money, and were not over-scrupulous about the methods used to attain this aim. ${ }^{15}$

In more recent settlement studies, this negative view of speculators has been partially revised. The work of R.P. Swierenga in the United States suggests that the speculators provided useful propaganda for the districts and leant order to a disordered system. ${ }^{16}$ Voisey's work on the Vulcan district reaches similar though less explicit conclusions. ${ }^{17} \mathrm{Specu}-$ lation on a grand and vulgar scale seems confined in the Peace to the well known corruption surrounding townsites such as Dunvegan and Grouard. Unlike Vulcan, the railway was delayed in approaching the Berwyn region. Moreover, the lack of railway land grants in the area meant that only a "bona fide" settler had access to the land. The combined impact meant land values in the Berwyn region never inflated to the degree they did in the south, and the region was spared from the rampant speculation prevalent in some areas of the south. 


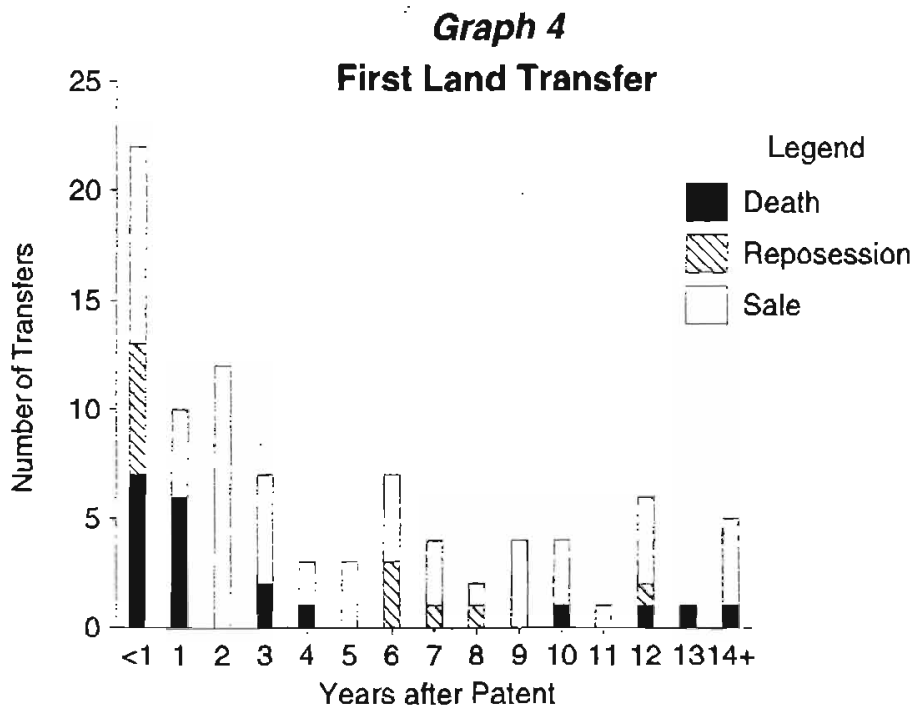

While the high cancellation rate suggests only the most determined succeeded in building a farm, proving up did not mean that a homesteader stayed in the district. Several successful homesteaders left the district soon after receiving patent for their land. Lyle Dick's work on Abernethy points to small scale petty speculation as one of the primary causes for this phenomenon, ${ }^{18}$ and it was a factor in the Berwyn district. A prime example was the Cyra family. August Cyra and his three sons all homesteaded in the district in 1914. The father and two sons came to the district from Ontario, the third son, from Enumclaw, Washington. At first, it appeared that the family made an attempt to farm the land, but by 1922 they all had Washington state mailing addresses. They obtained patents for their homesteads between 1921 and 1923 and sold them within a year to August's brother-in-law, Enumclaw resident Arthur Cota. Mr. Cota made several attempts to sell the land at inflated values and was finally successful selling the patents as a unit to a newly arrived farmer in $1927 .{ }^{19}$ Early work in the United States by Paul Gates suggested that this petty speculation placed undo hardship on "bona fide" settlers. The absentee landlords often withheld their uncultivated plots, thus depreciating the overall value of district land. Moreover, the speculators did not fulfil their tax obligations, and, because their land had a lower assessed value, they increased the strain on the district taxpayers in maintaining infrastructure. Little evidence of absentee land owners avoiding taxes in township 83-25-W5 could be discovered, and tax problems in the M.D. of Peace can be traced more easily to other issues. 


\section{Past Imperfect}

\section{"The Great War and The Soldier Settlement Board"}

The timing of settlement in Township 83-25-W5 was another important factor bearing upon the rate of settlement. The homesteading of the district occurred concurrently with the beginning of the Great War and the per-capita enlistment from the Peace River district was unusually large. ${ }^{20}$ Given the population base of the region -- a larger number of young single males -- proportionately higher enlistment was not unreasonable. From township 83-25-W5, at least 20 homesteaders enlisted. In some cases, a prospective settler filed for homestead and then joined the Canadian Expeditionary Force immediately. ${ }^{21}$ The improvements necessary for patent were thus delayed until after the war. In six cases, the homesteader was killed in action and the land patented to his estate and subsequently sold. The remaining veterans must have found the transition back to farming extremely difficult. Only seven of the fourteen remained in the district by 1926 .

While the delay in improving land in the district had a bearing on settlement patterns, the post-war adjustment programs had the greatest impact on the region. Under the terms of the Soldier Settlement Act (1919), many of the veterans were entitled to assistance in the form of land grants or loans. ${ }^{22}$ In township 83-25-W5 and, indeed, in the entire M.D. of Peace, most veterans who claimed assistance from the Soldier Settlement Board (SSB) did not succeed. The SSB provided five loans and five soldier grants to the settlers in township 83-25-W5, and another settler received a soldier grant in an adjacent township. ${ }^{23}$ Two of the soldier grants were made to new settlers in the township, and one loan was provided to a new settler purchasing land. The two former soldiers receiving grants had very different experiences. One, Ernie Leitch, also filed a homestead and succeeded in proving up on both quarters. The second, Sam Fitzgerald, had his request for patent denied in 1926 and the patent was issued to the SSB. Two farmers who had homesteaded in the district prior to enlistment, George Johnson and Frank Cooley, received soldier's grants and loans to develop their homesteads. Johnson sold his homestead in 1925, but the patents to his grant and to Cooley's quarters were seized by the SSB for non-payment on the loans. Another district homesteader, Harry Bolt, received a soldier grant, and, although he eventually patented his homestead, his soldier grant was rescinded. In the three cases where only loans were provided, only one succeeded. The SSB rescinded the contract in one case and seized the land in the other.

As a result of the soldier settlement policy, the SSB ended up with the patents to five quarters in the township. It also found that by 1931, 9 quarters with SSB assistance in the township and 69 in the M.D. of 
Peace had tax problems. ${ }^{24}$ The SSB, however, refused to pay the taxes. The M.D. had always managed to get tax payments from lending institutions through its power to seize land. A lender took the land as collateral for the loan, but if the M.D. seized it, the collateral disappeared. Hence, to protect their interests, mortgage holders often paid taxes on the property. The SSB, however, took a significantly different position. When it seized land, it demanded that the land be treated as crown land and thus outside the tax structure. ${ }^{25}$ It also put its claim ahead of the M.D.'s. This placed the M.D. in a difficult position. They had budgeted and set tax rates based upon their total tax base. The SSB actions simply removed some of the tax base without any compensation. Although the SSB did finally reach an agreement with the municipal governments throughout the west in the 1930s, the financial stress its actions placed on the municipal tax structure was far more significant than the activities of the petty speculators.

\section{"Municipal Taxes and Other Issues"}

The Municipal District of Peace was organised in 1917, and land taxes were immediately assessed. One homesteader recalled that taxes were an important consideration in the decision of many early settlers to sell. ${ }^{26}$ Because the M.D. did nor enforce tax collection until the patent for the land had been granted, many settlers accumulated tax bills of $\$ 300$ or more. Hence, sertlers ofren faced huge tax problems immediately after receiving their patents. Large tax arrears were an issue in ten of the twenty-four transfers which occurred within two years of patent. ${ }^{27}$ Although the M.D. was, in practice, quite lenienc in its dealings with arrears -- in all cases but one, it waited three years after patenting to file a tax collection notice and from five to six years before seizing the land -- the threat of repossession certainly influenced some land owners to sell.

In at least two cases, the strong family nacure of the original setrlement also played a role in early sales of land. In 1919, following the death of his son just one year after title to the land had been received, Benjamin La Prette sold both quarters. A pair of brothers had a similar experience. Caspar and Chris Knutson came to the Berwyn district from Oregon in $1917 .{ }^{28}$ Caspar paid no taxes on his land, and, shortly after receiving title in 1923, he sold it to another district farmer. Chris had received title to his quarter in 1923 as well but, unlike his brother, had paid all of his taxes. His intention to stay was indicated by his wife's position as teacher at the small country school in the district. ${ }^{29}$ Yet one year after his brother had left, Chris also sold his land. While it is impossible to know if the family sales were related, they do represent another possible cause of early decisions to leave. 


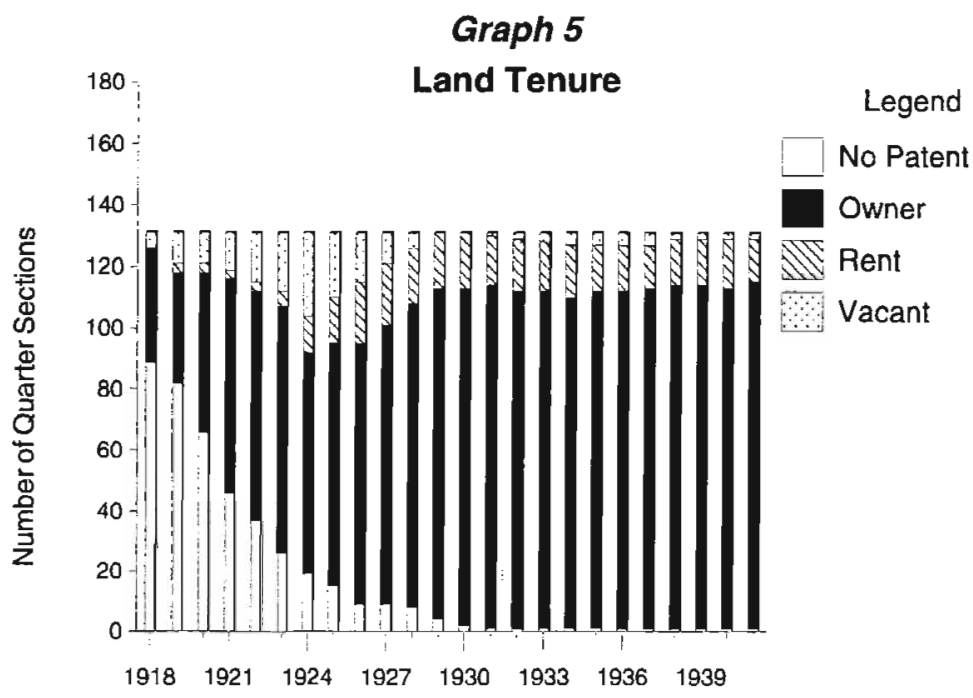

Land Transfer and Farm Expansion

The stability of the population in the township is even more remarkable when the large scale transfer of lands in the period 1926-31 is taken into account. Examining the transfer of land following patenting of a homestead helps to explain why settlers moved into the district and why they left, but it distorts the chronological aspects of land transfer and, consequently, can be misleading. Patenting in Township 83-25-W5 occurred throughout the period, and no pattern for either the length of homestead period or the date of patenting exists. When analysing the transfer of land on a chronological basis, however, a significant trend is apparent.

The year 1926 quickly becomes important as a transition year when one looks at the overall land tenure pattern in the township. The timing of settlement in the Peace country once again becomes important in explaining the conditions. The severe post-war economic slump devastated the Peace country. Depreciating wheat prices combined with abnormally high transportation costs led to financial insecurity. Because few settlers had an opportunity to become well established on the land before the depression, out-migration occurred at high levels. The large number of vacant quarters in the township 1922-4 testify to the severity of the depression, but it also provided a readily available source of land for expansion as economic conditions improved. There were 


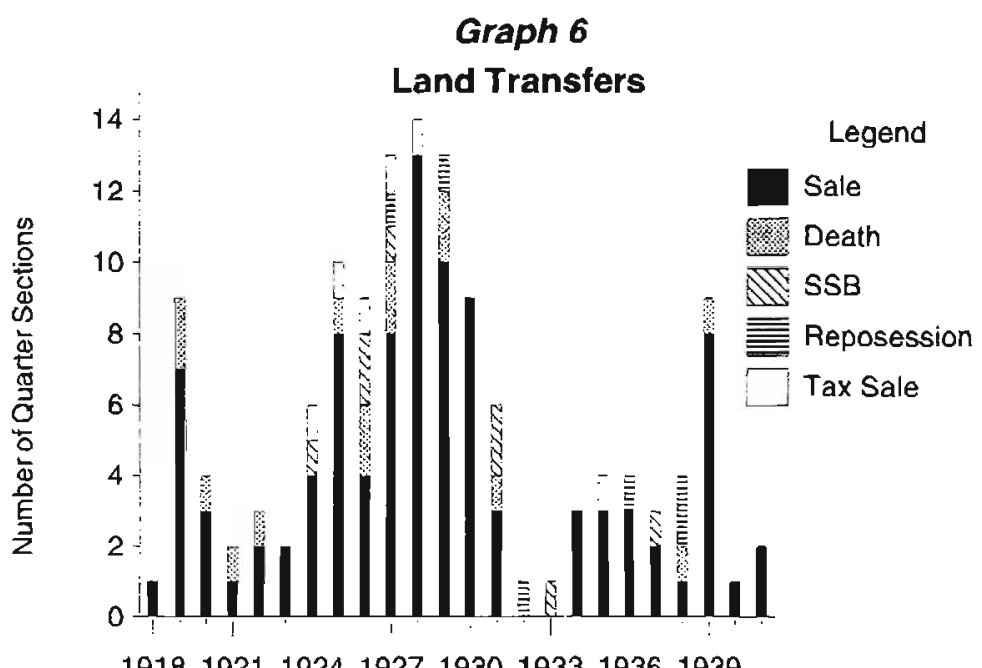

thirty-six patent holders living outside the district in 1924, and only three appeared to be farmed by the absentee owner. ${ }^{30}$ Seventeen of the quarters owned by non-residents changed hands between 1926 and 1931. Another eight were sold before 1941.

The number of quarters which ended up in the hands of homesteader's estates or in the hands of the M.D. during this period also encouraged transfers. Eleven homesteaders in the district died between 1918 and 1925 leaving estates or widows in control of the land (Graph 6). These lands, with only three exceptions, were sold between 1926 and 1931. Ac the same time, the M.D. sold seven quarter sections which it had seized for non-payment of taxes between 1924 and 1928. Those who sold to prevent seizure must also be added to this list. While estate land was often rented prior to being purchased, the repossessed land was sold as quickly as possible.

Prior to 1926, prices for land in the township were too low to make selling the land worthwhile. The large number of farms for sale and the reputation the district had for early frosts combined with the uncertainty caused by the post-war depression to keep prices low until 1927.31 An absentee landlord thus could leave the land vacant or find a renter. The number of vacane quarters in the township peaked ar 27 in 1924, and the number of rented quarters slowly increased to 20 in 1926 (Graph 5). ${ }^{32}$ The Census makes it clear that renting was a common practice in the M.D. of Peace and that the renters were primarily local farmers as the practice of jointly renting and owning increased during 


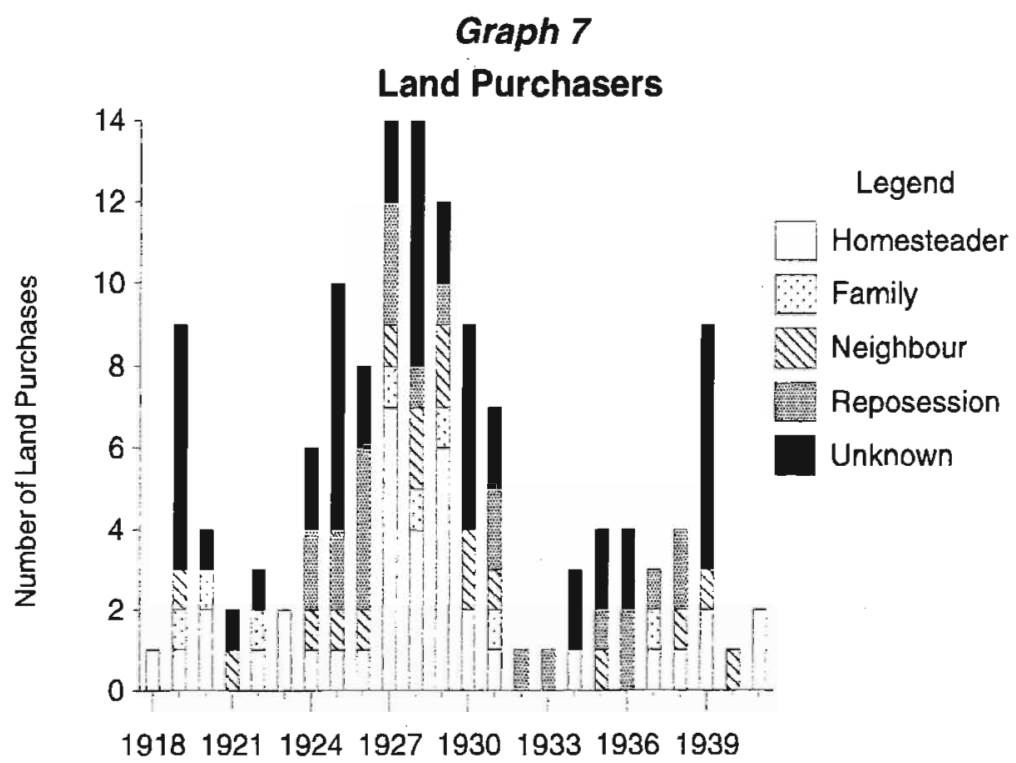

this period. ${ }^{33}$ Renting a farm allowed the farmer to operate a larger farm with minimal risk. Moreover, it expanded production and encouraged the farmer to purchase machinery. It became important in the township at a much earlier date in the district's development because the land became available due to the depression. Eventually, either the renter or another farmer would purchase the land.

Unlike the experience in the southern prairies, however, the number of quarters rented in the region as a proportion of patented land decreased significantly with the impact of the recovery. ${ }^{34} \mathrm{~A}$ large amount of land in the township changed hands in the period 1926-31. This transfer of lands can be explained by returning to the unrealistic Dominion settlement scheme in the Peace country.

The Census of the Prairie Provinces in 1926 revealed that a major restructuring occurred between 1921 and 1926. The total number of farms decreased from 412 to 378 . The proportion of improved land within the M.D. of Peace, however, increased from 33\% to $45 \%$. New breaking often entailed the expensive process of clearing willows and aspen. ${ }^{35}$ To continue increasing their level of productivity, the farmers of the Berwyn district began to purchase land. In the southern prairies, railway, school, and $\mathrm{HBC}$ quarters provided an unoccupied land base for future expansion. In the Berwyn district school lands were sold in 1928 and all other expansion had to occur through the displacement of settlers in the district. These homesteaders began to acquire excess land 


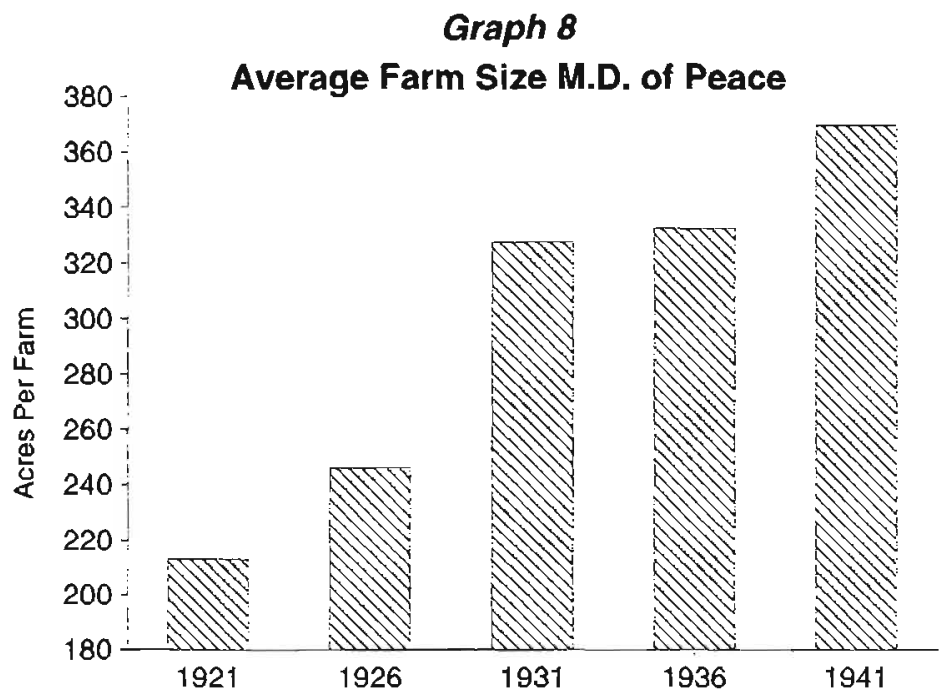

in the district. Graph 7 shows that district homesteaders were the largest purchasing group between 1926 and 1931. When combined with the large role played by farmers from neighbouring districts, it is clear that farm consolidation definicely occurred during the period. The number of farms in excess of 300 acres wholly within township 83-25-W5 increased from 14 to 26 between 1926 and $1931 .{ }^{36}$ Although there were some exceptions, most of these farms then grew over time. In 1941, there were still 25 farms over 300 acres in the township, and the farms of less than 300 acres continued to decline. This is reflected in the census results for the M.D. of Peace which show a continuous increase in average farm size throughout the period. (Graph 8)

While the limitations of the methodology prevent a statistical analysis of farm size in township 83-25-W5 (see Appendix A), specific examples may demonstrate the importance of this phenomenon. Berween 1931 and 1941, the holdings within the township of Percy Ireland increased from 3 to 5 quarters and those of Ernie Leitch, from 3 to 4 . Several other farmers had similar increases.

The high level of turnovers also coincided with a settlement boom in the whole of the Peace River district. ${ }^{37}$ In the Berwyn district, the actual settlement rush began in 1925. The Central Canadian Railway had reached Berwyn in 1922 improving access to markets for the areas produce. The government provided another incentive to new settlers in 1925 when it reduced the freight rates between Peace River and Edmonton from mountain to prairie standard. ${ }^{38}$ The improved market 


\section{Graph 9}

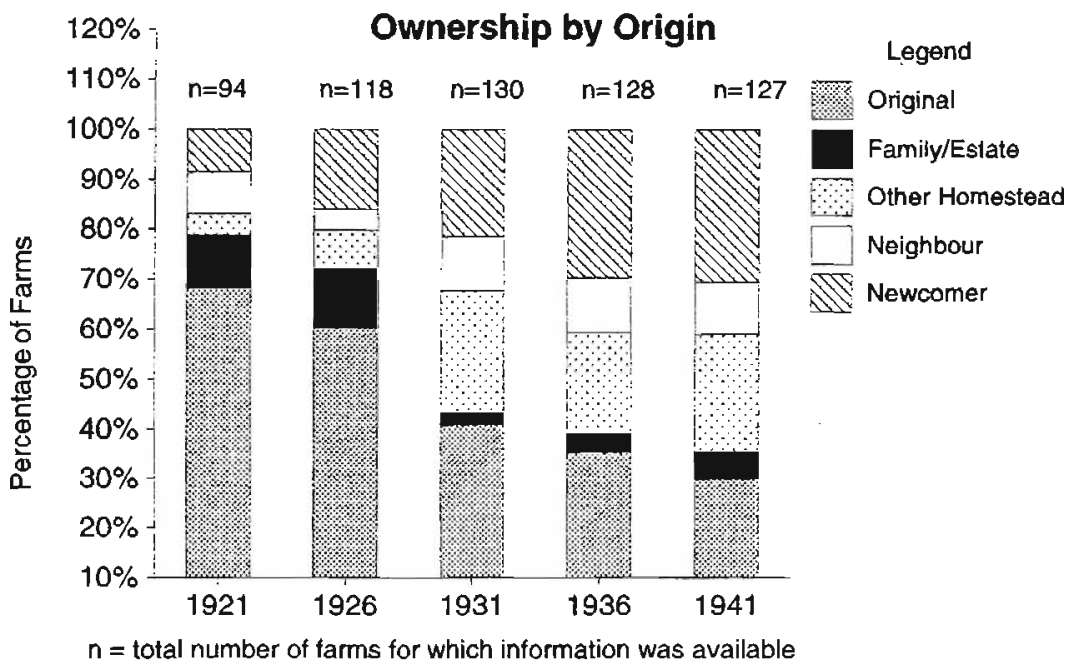

accessibility had a pronounced impact. Between 1922 and 1925, only 2 new households appeared in the township, compared with 11 in the period 1926-31. The proportion of newcomers owning land would continue to increase throughout the period. Nearly all of these newcomers had to purchase land from established farmers because only two quarters were available for homesteading after 1921. Between 1921 and 1931, farm land consolidation and increased immigration into the region combined to reduce dramatically the amount of land in the hands of the original patent holder. Despite this development, the amount of land in the hands of farmers who originally homesteaded in the township remained relatively high (Graph 9).

No variation between the original homesteaders and newcomers to the district could be found in ownership of the expanded farms. In 1941, the original homesteaders and their families controlled 15 or $60 \%$ of the consolidated farms totally within the township. They represented $58 \%$ of the total number of households in 83-25-W5. While the two largest farm operators in the township-- Steve Schur and Jacob Meyers -- both homesteaded in the region, newcomers like A.F. Murphy and Alexander Jackson also owned more than 4 quarters.

The land tenure pattern also reveals that the Great Depression never had the same substantive impact on the district as that produced in the period 1921-25. Land sales were certainly curtailed as wheat prices fell in 1931 and 1932, but the tremendous economic dislocation of the 


\section{Graph 10}

Persistance

Legend Inside $\begin{aligned} & \text { Outside } \\ & \text { District } \\ & \text { District }\end{aligned}$

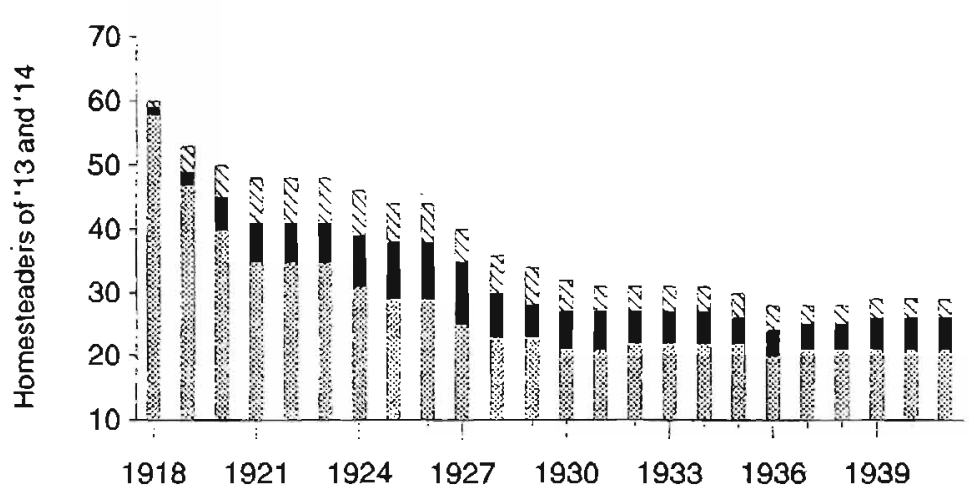

earlier period never occurred. Tax problems developed for several farmers, but neither farm vacancy nor tenancy seem to have increased dramatically. The population of the district remained stable and land sales were maintained at marginal levels following the recovery from the period 1932-35 (Graph 6). J.C. Malin, in a study of sertlement in Kansas, pointed out that depressed economic conditions reduced the level of in-migration, thus reducing competition for land purchases. ${ }^{39}$ As well, new settlers to the Peace River country still had the option of homesteading free land in several areas. Because most local farmers had already consolidated their holdings and few new settlers were arriving, purchasers did not exist for those desiring to sell land. Hence, the majority of transfers during the depression occurred near the end of the period as larger farmers returned to prosperity and purchased land from their smaller neighbours.

\section{Persistence on the Land}

One of the most important findings of land tenure studies is the high mobility of the settlement population. In separate studies, Lyle Dick and J.W. Bennetr both discovered that the original settler population quickly left the land. Bennetr found that $62 \%$ of the original homesteaders around Cyprus Hills left within the first twenty years. ${ }^{40}$ Dick indicated that significant variation could occur between districts. ${ }^{41} \mathrm{His}$ chart indicates that both Abernethy and Neudorf experienced signifi- 
cant out-migration of the original patent holders, but the movement was much faster in the Neudorf region. Within 10 years, $70 \%$ had left the Neudorf area, whereas, in the Abernethy area, $40 \%$ still remained after 20 years. The original homestead population of township 83-25W5 was indeed unstable, sustaining these earlier conclusions. While Bennett discovered that $28 \%$ of the homesteaders left within ten years and another $34 \%$, within twenty, nearly $59 \%$ of the homesteaders in township 83-25-W5 left within ten years of patenting, thus approaching the levels of the Neudorf area. The similar compact settlement pattern in the Berwyn and Neudorf areas may help explain the parallel. But the specific conditions produced by the post-war depression, the SSB activities, and speculation in the district must also be considered.

Richard Bremer used a factor referred to as the Gross Persistence rate to detail high mobility amongst Nebraska farmers. ${ }^{42}$ He explained that, over a twenty year period, only $20 \%$ of the original farmers in a district remained. Using Bremer's method, the population of township 83-25W5 also appears unstable. Taking the original settlers and their estate to represent a household, of the 126 households in the township in 1921 , only 41 or $32.5 \%$ remained in 1941 . This apparently high mobility rate is distorted by the net population change which occurs in the township. If the net decline in the population is taken into account, the results change dramatically. Graph 10 shows that the number of homesteaders from the years 1913 and 1914 remaining in the township over time decreased consistently until 1926. Following 1926, it stabilised and remained relatively constant for the next fifteen years. Of the 79 households in the township in 1941,41 or $52 \%$ were original homesteaders, and 46 or $58 \%$ owned land in the district prior to 1921 . Furthermore, if the year 1926 is used as a base - this compensates for the post-war depression -- the number of farmers persisting on the land increases to 55 . Thus in 1941 , fully $70 \%$ of the farmers in the township had lived there for fifteen or more years.

\section{Conclusions}

Any study of an area as small as a township can not propose to make sweeping conclusions. Too many anomalies could occur in the locale to make any such conclusions useful. This does not reduce the study of land tenure in township 83-25-W5 to obscurity. The experience in the township does provide limited insight into the larger process of frontier settlement. By 1941, a relatively stable family oriented farm population lived in the township. Many of the original homesteaders were gone. The settlement pattern, land speculation, war, death, and post-war depression had all contributed to their exodus. After the initial land 
turnover of the homestead period, the population stabilised at rational levels and the district developed towards maturity. A second wave of settlers in the years after 1925 had joined with the remaining homesteaders to consolidate the land into larger farms. Encouraged by the improved economic conditions and the arrival of the railway at the local community of Berwyn, these farmers expanded their land holding at the expense of smaller farmers in the district. Absentee land owners found many of the large farmers at first willing to rent their land and then to purchase it. This growing base of large farmers became the stabilising factor in the population of the region. Although initial population fluctuation, consolidation of farm units, and a general decline in the population were experienced by many frontier regions, the special conditions in the Berwyn district created a distinct community. The impact of the war, combined with the unrealistic settlement pattern, forced the rationalisation of the population levels to occur earlier than in other frontier regions. Consequently, the population of the Berwyn district demonstrated several characteristics of an older more marure society. Despite the many similarities in the development of frontier regions, township 83-25-W5 suggests that each will have its own peculiar distincriveness. 


\section{APPENDIX: METHODOLOGY}

The statistical data used in this essay was compiled from the Dominion of Canada Homestead files, the Municipal District of Peace \#857 tax rolls and correspondence files, and the Census of Canada. One hundred and thirty-one quarter sections were available for settlement in Township 83-25-W5, and 128 settlers homesteaded within it (three homesteaders used the provisions of the Soldier Settlement Act to file on a second quarter within the township). Brief biographical sketches of 126 of the 128 successful homesteaders were obtained from the homestead files. Once the original occupant of the land was determined, the tax rolls of the Municipal District, created in 1917, were consulted for changes in title or utilisation of the land. The information compiled from these sources was compared to the statistical data in the census.

A township was selected as the basic unit for the study because the land records are catalogued in township units. Farmers, however, do not necessarily occupy the land in this manner. Several farm units may be spread over two or more townships. Moreover, the Post Office and school districts -- often the source of community identity and the primary focus of community activities -- do not use a township as a determinant in their boundaries. Consequently, the use of the township created certain problems. The size of farms in the region and changes in size overtime were especially difficult. The data base for those units restricted solely to the township was too small to create meaningful charts or tables. Certain factors, however, were addressed. In cases where farmers from the neighbouring townships were identified as land owners in the township, they were catalogued separately. Furthermore, they were not considered as a household living within the township.

The reliability of the tax rolls for changes in land tenure must also be considered when analysing the data. Rather than land title records, the tax rolls represent a log of the people paying taxes on the property. Usually the tax payer was the land owner but certain inconsistencies in the records suggest that occasionally, the Municipal District listed tenants. The general correspondence files of the M.D. were essential in correcting this problem. In circumstances where the problem was detected, it was rectified. Nevertheless, in a few cases, this situation undoubtedly escaped detection.

The methodology also makes it difficult to determine tenant farming patterns. Small notes sometimes appear in the tax roll regarding the renting of land. These cannot be used as a reliable indicator, however, because they appear and disappear with no consistency. Other indications of renting have thus been examined. At times, a new tax payer appeared in the tax roll only to be replaced by the original tax payer's 
name a few years later. This situation indicates either a failed purchase attempt, or a rental agreement. Moreover, a number of tax payers had addresses outside of the district and their land would have been the obvious choice for renting. This indicator has only a limited usefulness because it does not distinguish between rented and vacant land. Once again the correspondence files of the M.D. proved useful. The Secretary of the district often acted as a land agent for absentee land owners and his files contain several rental agreements. Furthermore, in general tax correspondence, land owners often made reference to renters or lack of renters on their land. In all cases when tenant farming was not suspected, a change in the tax roll was assumed to be a change in ownership. Even combining all of these factors the farmer on 10 quarter sections in 1941 could not be determined. Thus, the picture of land rental and vacancies compiled is merely suggestive.

The variables in these calculations force the conclusions to be made in relarive racher than absolute terms. Without access to the manuscript census returns, the information is the best available. Because graphs demonstrate trends and patterns which can accommodate certain small variations, they have been used in lieu of tables. 


\section{NOTES}

'David Ellis, ed., The Frontier in American Development: Essays in Honour of Paul Wallace Gates, (Ithaca, 1969). The following volumes of the Frontiers series are especially significant: W.A. Mackintosh, Prairie Settlement: The Geographical Setting (Toronto, 1934); idem, Economic Problems of the Prairie Provinces (Toronto, 1935); R.W. Murchie, Agricultural Progress on the Prairie Frontier (Toronto, 1936); Chester Martin, Dominion Lands Policy (Toronto, 1938); and C.A. Dawson, The Settlement of the Peace River Country (Toronto, 1934).

${ }^{2}$ For those interested readers, a detailed explanation of the methodology is provided in the Appendix

${ }^{3}$ For a look at excerpts of several of the earlier reports see Gordon Bowes, Peace River Chronicles (Vancouver, 1963). The government position on Macoun's report is examined in W.A. Waiser, "A Bear Garden: James Melville Macoun and the 1904 Peace River Controversy," Canadian Historical Review 67 (1986), 4950. See Canada's Fertile Northland: Report and Evidence of the Select Committee of the Senate of Canada, 1906-7(Ottawa,1907) for the Canadian position despite Macoun.

${ }^{4}$ Canada, Department of the Interior, Description of Surveyed Townships in the Peace River District of Alberta and British Columbia, 3rd Edition (Ottawa, 1916), 162

5 James Richrik, "The Policy Framework for Settling the Canadian West, 18701880," Agricultural History 49:4(1975), 613-28; Lyle Dick, Farmers "Making Good": The Development of Abernethy District, Saskatchewan, 1880-1920 (Ottawa, 1989), 18-9; John L. Tyman, By Section Township and Range (Brandon, 1972), 210; Paul Voisey, Vulcan: The Making of a Prairie Community (Toronto, 1988), 43

${ }^{6}$ D.J. Hall, "Clifford Sifton: Immigration and Settlement Policy, 1896-1905," in The Settlement of the West, ed. Howard Palmer (Calgary, 1977), 63-4

${ }^{7}$ Provincial Archives of Alberta (hereafter PAA), Homestead Files, 2476426 and 2476428

${ }^{8}$ Voisey, Vulcan, 13-6. The major difference between Vulcan and the Berwyn district is the higher proportion arriving directly from the United States in Vulcan.

9 Dick, Farmers “Making Good", 39

${ }^{10}$ Work on Ukrainian settlement in Canada has reached similar conclusions. See for example, John Lehr, “The Peculiar People': Ukrainian Settlement of Marginal Lands in Southeastern Manitoba," in Building Beyond the Homestead, eds. David C. Jones and Ian MacPherson, (Calgary, 1988), 29-46.

"Martin, Dominion Lands, 395

12 Voisey, Vulcan, 44; Dick, Farmers "Making Good", 38

${ }_{13}$ PAA, Homestead Files, 3008547, 3008549, 3008551, and 3008567

${ }^{14}$ Brick's Hill, Berwyn and Beyond: A History of Berwyn and District, (Berwyn, 1967)

${ }^{15}$ Dawson, Settlement of Peace River, 39

${ }^{16}$ R.P. Swierenga, "Land Speculation and its Impact on American Economic Growth and Welfare: A Historiographic Review," Western Historical Quarterly 
8(1977), 294-98

${ }^{17}$ Voisey, Vulcan, 48-51

18 Dick, Farmers "Making Good", 31

${ }^{19}$ Letters berween A. Cota and J. Lamont, various dates, PAA, M.D. of Peace Correspondence Files, Acc. 71.336, file 3

${ }^{20}$ Dawson, Settlement of Peace River, 42

${ }^{21}$ For examples of this see PAA, Homestead files, 3172624, 3200442, 3219170, 3396969,3618622 , and 3832452 . In other cases, a claim was filed before going on acrive service, but never acted upon and later cancelled. See files 3236279 and 3236291 .

\section{${ }^{22}$ Statutes of Canada, 1919, c. 71, The Soldier Settlement Act}

23 PAA, Homestead files 3008549, 3089302, 3190687, 3194993, 3195027 , $3200438,3216749,3236291,3791508$, and 3832542

${ }^{24}$ PAA, M.D. of Peace, Acc. 71.336, file 146, J.M. Varney (SSB) to T.E. Evans, March 14, 1932

${ }^{25}$ Ibid. See especially files 32, 146, and 210 .

${ }^{26}$ Brick's Hill, Beruyn and Beyond, 160-175

${ }^{27}$ The 24 transfers exclude the SSB Repossessions and transfers due to death. The problem with tax arrears did not exclude specularors. Afrer all, a speculator is looking for a profit by turning the land over quickly and would not be interested in paying taxes. Nevertheless, in some cases taxes may have been the deciding factor rather chan a symptom.

${ }^{28}$ PAA, Homestead Files 3298828 and 3396971

${ }^{29}$ Peace River Record June 28, 1923

${ }^{30}$ Murchie points our that a similar phenomenon occurred in the sub-marginal lands of Northern Manitoba (Agricultural Progress, 108-9). Although land abandonment was not as serious in the Peace Country, the number of absentee land owners reached $29 \%$.

31 PAA, M.D. of Peace, Acc. 71.366, file 40, E.L. Lamone to Mrs. Agnes McCrum, August 27, 1926; Ibid., file 19, E.L. Lamont to Royal Bank, August 23, 1927; Ibid., file 2, E.L. Lamont to Mrs. Clara Black, February 14, 1927

32 These numbers should not be considered conclusive. The methodology used tends to underestimate renting.

${ }^{33}$ Murchie, Agricultural Progress, 117-25. Murchie points out that owner-tenancy and tenancy were two distinct land tenure systems caused by different factors.

${ }^{31}$ Murchie has starisrics for the entire prairies 1921-1931 (Agricultural Progress, $115)$. In the $\mathrm{Vulcan}$ region, for example, the largest and most progressive farmers represented the group most active as renters (Voisey, Vulcan, 136-7).

35 Dawson estimated cost of breaking in 1930 at $\$ 10-\$ 20$ /acre depending upon the difficulty encountered. See Dawson, Settlement of Peace River, 81.

${ }^{36} \mathrm{Ibid}$. 56. Dawson's figures on average farm size indicare a decrease in the period 1926-31. This apparent contradicrion may be explained by the opening of several new districts to homesteading during the period.

37 Brick's Hill and Beyond, 212; Dawson, Settlement of Peace River, 44

${ }^{38}$ Peace River Record 3 Sept. 1925 
39 J.C. Malin, "Turnover of Farm Population in Kansas," Kansas Historical Quarterly (1935), 342

${ }^{40} \mathrm{~J}$.W. Bennett, "Adaptive Strategies and Processes on the Canadian Plains," in A Region of the Mind, ed. R. Allen (Regina, 1973), 196-7

${ }^{41}$ Dick, Farmers "Making Good", 40

${ }^{42}$ Richard Bremer, "Patterns of Spatial Mobility: A Case Study of Nebraska Farmers, 1870-1970," Agriculture History 48 (1974), 535 